\title{
The Distribution and Degradation of Chlormequat in Wheat Plants
}

\author{
H. M. Dekhuijzen and C. R. Vonk \\ Institute for Organic Chemistry T.N.O., Utrecht, The Netherlands, Centre for Plant \\ Physiological Research, Wageningen, The Netherlands
}

Received December 10, 1973; accepted February 4, 1974

\begin{abstract}
The distribution and degradation of chlormequat chloride (2-chloro $1,2-{ }^{14} \mathrm{C}$ ethyltrimethylammonium chloride) was determined after uptake by the roots of summer wheat seedlings. This plant regulator was readily translocated from the roots to the above ground parts and converted into choline. Choline was further metabolized to betaine which upon demethylation yielded finally glycine and serine. Both amino acids were incorporated into a protein fraction.

The occurrence of radioactively labeled glycine and serine in the amino acid pool and the evolution of ${ }^{14} \mathrm{CO}_{2}$ from chlormequat treated plants indicated that serine was formed from glycine under the release of ${ }^{14} \mathrm{CO}_{2}$ during photorespiration.

One week after the uptake period $82 \%$ of ${ }^{14} \mathrm{C}$ chlormequat taken up by the roots was recovered as the parent compound or as breakdown products in wheat plants. In addition $5 \%$ of the amount taken up by the roots was released as ${ }^{14} \mathrm{CO}_{2}$ by the leaves.

Fif ty per cent of the total amount of chlormequat originally present in roots and leaves was already metabolized after 7.5 days. No evidence has been obtained for the presence of unchanged chlormequat or an unknown metabolite in the nucleic acid or protein fraction.
\end{abstract}

\section{INTRODUCTION}

The growth regulator chlormequat, the chloride salt of which is CCC (2-chloroethyltrimethylammonium chloride), is widely used to prevent lodging of wheat (1-3). Conflicting results have been reported on the fate of chlormequat in wheat and other plants. According to Blinn (4) and Birecka (5) the compound undergoes very little or no metabolism. On the other hand it has been reported repeatedly that chlormequat is converted into choline (6-12) :

$\mathrm{ClCH}_{2} \mathrm{CH}_{2} \mathrm{~N}\left(\mathrm{CH}_{3}\right)_{3} \rightarrow$ chlormequat

$\mathrm{HOCH}_{2} \mathrm{CH}_{2} \mathrm{~N}\left(\mathrm{CH}_{3}\right)_{3}$ choline
Only a few data are available about the rate of disappearance of chlormequat from wheat plants. Jung and El-Fouly (10) found a complete breakdown to choline within 10 days, whereas Mooney and Pasarcla (13) and Bier and Dedek (7) showed a biological half life for chlormequat of 13 and 25 days, respectively. In contrast, Birecka (5) and Bohring (8) reported that the total amount of chlormequat (radioactively labeled) did not decrease during a $4 \mathrm{wk}$ period in wheat. It is diluted by plant growth which results in a decrease of chlormequat per gram dry weight material.

In general the plant material is extracted with ethanol or methanol and little attention has been paid to the radioactivity which ends up in the residue after alcohol extraction. Schneider (11) found that 
$60-85 \%$ of the added radioactively labeled chlormequat was recovered in the ethanolic filtrates, the rest being in the residue. It is known that alkyl halogens can react with sulfhydryl groups of cysteine and glutiathione to produce thioethers (14). On the other hand Brook et al. (15) assume a binding of phosphon $S,(2,4$-dichlorobenzyltributylammonium-chloride) a growth regulator which also contains a quarternary ammonium group, to the nucleic acid fraction. The residue after alcoholic extraction cortainly contains both nueleic acids and proteins and it seemed of interest, therefore, to determine whether chlormequat or a metabolite oceurred in the nucleic acid or protein fraction.

This paper then deals with the fate and distribution of chlormequat in different fractions of wheat scedlings.

\section{MATERIALS AND METHODS}

\section{Growth of Wheat Seedlings}

Summer wheat seedlings (Triticum aestivum L. cv. Juffy) were grown for 1 wh on Pcrlite (heated vulcanic rock, Pull, Rhenen, The Netherlands) and watered with a nutrient solution $\mathrm{pH} 6(16)$ at $20^{\circ} \mathrm{C}$ in a growth chamber. The plants received 65700 erg $\mathrm{em}^{-2} \mathrm{~s}^{-1}$ (Philips HPL fluoreseent lamps, and incandescent lamps with a radiation region of $400-700 \mathrm{~nm}$ ) for $12 \mathrm{hr}$ per day. Twenty, one week old, seedlings with one fully grown leaf were transferred with the roots to $8 \mathrm{ml}$ of the nutrient solution in a glass beaker without Perlite. The growth regulator, $1,2-{ }^{14} \mathrm{C}$ chlormequat $(4.49 \mu \mathrm{Ci})$ made up to a final concentration of 0.115 $m M$ was added to the solution. Six hours later this solution was replaced by the nutrient solution and the plants were harvested 0,7 , or 14 days later.

\section{Radioactive Chlormequat}

The growth regulator, 2-chloro-1,2- ${ }^{14} \mathrm{C}$ ethyltrimethylammonium chloride was obtained from $\mathrm{N}_{\mathrm{e}}$ w England Nuclear Corp.,
Boston, Mass. (sp act $4.81 \mathrm{mCi} / \mathrm{mmole}$ or $30.5 \mu \mathrm{Ci} / \mathrm{mg})$. Radiopurity was established by chromatographing a sample in $n$-butanol-othanol-acetic acid-water $(8: 2$ : $1: 3)$. The sample contained $98 \%$ chlormequat $\left(K_{f}, 0.58\right)$ and $2 \%$ unknown compounds, one cochromatographing with choline $\left(R_{f} 0.45\right)$.

\section{Counting}

All extracts and chromatograms were counted in a Nuclear Chicago Mark I liquid seintillation spectrometer. Aliquots of $0.1-1 \mathrm{ml}$ of the various solutions were dissolved in $10 \mathrm{ml}$ scintillation liquid. The composition of the scintillation liquid is given by Veen (17).

\section{Evolution of ${ }^{14} \mathrm{CO}_{2}$}

In a fow experiments the plants were placed for one week in a closed glass chamber after the uptake period. Air was circulated through the glass chamber and ${ }^{14} \mathrm{CO}_{2}$ trapped in two different successive flasks connected with each other and filled with 100 and $50 \mathrm{ml}$ phenylethylamine, resp.

\section{Combustion}

Aliquots not exceeding $10 \mathrm{mg}$ of dried residues of plant material wore combusted with pure oxygen in scintillation flasks (Micro-Mat BF 5010, Berthold-Frieseke, Karlsruhe, B.R.D.). Liberated ${ }^{14} \mathrm{CO}$. was trapped for counting in phenylethylamine as described by Fuchs and de Vries (18).

\section{Sample Preparation}

Zero, seven and fourteen days after uptake of chlormequat the plants were removed from the nutrient solution and thoroughly cleaned with $50 \mathrm{ml}$ water. Roots and foliage were separated and immediately extracted with phosphate buffer (Fig. 1). Aliquots of the nutrient selutions and washings were counted to 
1. grind plant material 8 times with sand in $15 \mathrm{ml}$ phosphate buffer $\mathrm{pH} 8$ centrifuge $2 \mathrm{~min}$ at $500 \mathrm{~g}$

2. supernatant centrifuge $20 \mathrm{~min} 20.000 \mathrm{~g}$ dry precipitate and combust

add TCA (final conc. $5 \%$ ) to $9 / 10$ of supernatant

4. wash precipitate 3 times with icecold $10 \mathrm{ml} 5 \%$ TCA and with $2 \mathrm{ml}$ diethyl ether

5. dissolve precipitate in $1 \mathrm{~N} \mathrm{NaOH}$ and pass solution with water through Sephadex G 50. Collect. protein fraction (void volume)

6. hydrolyze protein fraction with $\mathrm{HCl}$ to amino acids

7. analyze hydrolysate on amino acid analyzer

3A. add $1 / 10$ of supernatant to Dowex $\mathrm{H}^{+}$column 1

4A. wash column with water (negatively charged fraction)

5A. elute column with $2.5 \mathrm{~N} \mathrm{HCl}$

6A. collect $5 \mathrm{ml}$ fractions of amino acids, choline + betaine, chlormequat

7A. electrophoresis or amino acid 7B. separate on paper analyzer
3B. combust precipitate (plastids and mitochondria)

FIG. 1. Flow chart of the procedure for extraction of chlormequat and breakdown products from wheat seedlings.

determine accurately the amount of chlormequat taken up by the plants.

For nucleic acid extraction the roots were removed and only the zone of $0.5 \mathrm{~cm}$ including the apex and subapical meristematic region of 20 plants were extracted directly after the uptake period.

\section{Nucleic Acid Extraction}

Nucleic acids, RNA together with DNA, were extracted essentially as described by Solymosy et al. (19). Fresh weight tissue $(210 \mathrm{mg})$ was ground with sand in a mortar and pestle and taken up in a medium containing $10 \mathrm{ml}$ of $0.1 M$ tris(hydroxymethyl)aminomethane (Tris)-chloride buffer, $\mathrm{pH} \quad 7.5$ and $2 \%$ sodium lauryl sulfate and $0.45 \mathrm{ml}$ diethylpyrocarbonate (Baycovin, Bayer Ltd. Leverkusen, B.R.D.). The homogenate was incubated at $37^{\circ} \mathrm{C}$ for $5 \mathrm{~min}$ and centrifuged at $8000 \mathrm{~g}$ for $15 \mathrm{~min}$ at room temperature. The supernatant to which $1.5 \mathrm{~g} \mathrm{NaCl}$ was added, was incubated at $37^{\circ} \mathrm{C}$ for $5 \mathrm{~min}$ and centrifuged at $10,000 \mathrm{~g}$ for $20 \mathrm{~min}$ at $4^{\circ} \mathrm{C}$. The supernatant was poured into 37 $\mathrm{ml}$ ice-cold $96 \%$ ethanol and kept for $2 \mathrm{hr}$ at $-15^{\circ} \mathrm{C}$ and centrifuged at $3000 \mathrm{~g}$ for 10 min at $4^{\circ} \mathrm{C}$. The precipitate was dissolved in $1 \mathrm{ml}$ glass distilled water and passed through a column $30 \mathrm{~cm}$ long and $2 \mathrm{~cm}$ diameter filled with Sephadex G 75 to separate nucleic acids from smaller molecules. Five $\mathrm{ml}$ fractions were collected, optical density (OD) recorded at $254 \mathrm{~nm}$ (OD 1 equals $0.05 \mathrm{mg} / \mathrm{ml}$ ). Half $\mathrm{ml}$ fractions were added to vials with $10 \mathrm{ml}$ scintillation liquid and counted.

\section{Protein Extraction}

The extraction procedure and clean up of the samples is summarized in Fig. 1. Plant material was ground with sand eight times in phosphate buffer $\mathrm{pH}$ 8. Aftcr centrifugation part of the supernatant was used to precipitate the proteins with trichloroacetic acid (step 3). After washing with diethyl ether (step 4) the precipitate was dissolved in $12 \mathrm{ml} 1 \mathrm{~N} \mathrm{NaOH}$ and passed in $3 \mathrm{ml}$ samples through a $26 \times 2$ cm column of Sephadex G50 to separate proteins from small molecules such as chlormequat. Fractions $(9.5 \mathrm{ml})$ were collected and $1 \mathrm{ml}$ of these fractions counted 
(step 5). Half ml fractions $4-7$ were used for determining the protein content with the Folin-Ciocalteu reagent (20). Crystallized bovine albumin (British Drug House) was used as a standard.

In a few cases the protein fraction was hydrolyzed in $5 \mathrm{ml} 6 \mathrm{~N} \mathrm{HCl}$ under reduced pressure for $24 \mathrm{hr}$ at $110^{\circ} \mathrm{C}$ and run on Spherix cation exchange resin, type 8-60-0 on an amino acid analyzer (Phocnix Precision Instr. Co. Philadelphia, Penn. U.S.A., Model 6800) with citrate buffer $\mathrm{pH} 3.25$ \pm 0.01 at a flow rate of $60 \mathrm{ml} / \mathrm{hr}$ (steps, $6,7)$. Non-labcled amino acids were used as standards and detected with a ninhydrin colorimetric analysis according to Rosen (21).

\section{Determination of Free Soluble Chlormequat, Choline and Betaine}

The presence of free soluble chlormequat, choline and betaine was determined by adding an aliquot of a sample (step 3A) to a $24 \times 1.1 \mathrm{~cm}$ bed of Dowex $50 \mathrm{~W}-\mathrm{X} 8$ (200-400 mesh, $\mathrm{H}^{+}$form) (22). After elution with $100 \mathrm{ml}$ water (negatively charged fraction) in step $4 \mathrm{~A}$ the compounds were eluted from the resin with $2.5 \mathrm{~N} \mathrm{HCl}$, collecting the effluent in $5 \mathrm{ml}$ fractions. Fraction numbers 1-6 contained amino acids and unknown compounds, fraction numbers 710 betaine and choline and fraction numbers 11-35 chlormequat (step 6A). The amino acid fraction was subjected to paper electrophoresis on What- man paper $3 \mathrm{MM}$ in citrate buffer $\mathrm{pH} 3.28$ at $30-35 \mathrm{~mA}$ and $105-130 \mathrm{~V}$ for $44 \mathrm{hr}$ (step $7 \mathrm{~A})$ or analyzed on the amino acid analyzer as described above.

The presence of chlormequat in the eluate from the Dowex column was determined by running the sample together with nonradioactively labcled markcr compounds on Whatman paper 3MM in n-butanolethanol-acetic acid-water $(8: 2: 1: 3)$ or in methanol-aceton-water $(30: 70: 2)$. Spots detected with Dragendorff's reagent (23) were cut out and radioactivity counted in scintillation liquid. The $R_{f}$ values of betaine, choline and chlormequat were, respectively, $0.31,0.37$, and 0.52 in the first solvent and $0.35,0.66$, and 0.75 in the second solvent (step $7 \mathrm{~A}$ ). Low radioactivity, due to unknown compounds, were found on other zones of the chromatograms and added to the amino acid fraction (see Table 2).

\section{RESULTS}

\section{Nucleic Acid Fraction}

Preliminary experiments showed that uptake of $0.1 \mathrm{~m} M$ chlormequat for $6 \mathrm{hr}$ by the roots was sufficient to cause a $20 \%$ growth inhibition of the third leaf $2 \mathrm{wk}$ later. At time of harvest 20 plants had taken up $3 \mu \mathrm{Ci}(4.9 \mu \mathrm{g})$ chlormequat chloride. In general, $90 \%$ of total radioactivity was recovered in the roots and only $10 \%$ in the above ground parts directly after the uptake period (Table 1).

TABLE 1

Analysis of 20 Wheat Plants Several Days After the Uplake of 1,2-14C Chlormequat by the Roots for 6 Hra

\begin{tabular}{|c|c|c|c|c|c|c|c|c|c|c|c|}
\hline \multirow{2}{*}{$\begin{array}{l}\text { Days } \\
\text { after the } \\
\text { uptake } \\
\text { period }\end{array}$} & \multirow{2}{*}{$\begin{array}{c}\text { Total } \\
\text { amount } \\
\text { taken up } \\
(\mu \mathrm{Ci})\end{array}$} & \multicolumn{2}{|c|}{$\begin{array}{l}\text { Water soluble } \\
\text { compounds } \\
(\mu \mathrm{Ci})\end{array}$} & \multicolumn{2}{|c|}{$\begin{array}{l}\text { Cell wall } \\
\text { residues } \\
(\mu \mathrm{Ci})\end{array}$} & \multicolumn{2}{|c|}{$\begin{array}{l}\text { Plastid } \\
\text { fraction } \\
(\mu \mathrm{Ci})\end{array}$} & \multicolumn{2}{|c|}{$\begin{array}{l}\text { Protein } \\
\text { fraction } \\
(\mu \mathrm{Ci})\end{array}$} & \multirow[t]{2}{*}{$\begin{array}{c}\text { Re- } \\
\text { covered } \\
(\mu \mathrm{Ci})\end{array}$} & \multirow[t]{2}{*}{$\begin{array}{c}\% \\
\text { Re- } \\
\text { covery }\end{array}$} \\
\hline & & Roots & Leaves & Roots & Leaves & Roots & Leaves & Roots & Leaves & & \\
\hline 0 & 3.174 & 2.362 & 0.360 & 0.000 & 0.000 & 0.019 & 0.007 & 0.001 & 0.000 & 2.750 & 86.6 \\
\hline 7 & 2.354 & 0.385 & 1.063 & 0.028 & 0.009 & 0.138 & 0.016 & 0.023 & 0.010 & 1.672 & 71.0 \\
\hline 14 & 2.332 & 0.121 & 0.773 & 0.022 & 0.000 & 0.077 & 0.011 & 0.042 & 0.005 & 1.051 & 45.1 \\
\hline
\end{tabular}

"For detailed analysis of water soluble compounds and protein fraction sce Table 2,3 and Fig. 2. 
TABLE 2

Distribution of Water Soluble Compounds from 20 Wheat Plants at Different Periods After the Uptake of $1,2-{ }^{14} \mathrm{C}$ Chlormequat

\begin{tabular}{|c|c|c|c|c|c|c|c|c|c|c|c|c|}
\hline & \multicolumn{12}{|c|}{ Days after the uptake period } \\
\hline & \multicolumn{4}{|c|}{0 Days } & \multicolumn{4}{|c|}{7 Days } & \multicolumn{4}{|c|}{14 Days } \\
\hline & \multicolumn{2}{|c|}{ Roots } & \multicolumn{2}{|c|}{ Ieaves } & \multicolumn{2}{|c|}{ Roots } & \multicolumn{2}{|c|}{ Leaves } & \multicolumn{2}{|c|}{ Roots } & \multicolumn{2}{|c|}{ I,eaves } \\
\hline & $\mu \mathrm{Ci}$ & $\%$ & $\mu \mathrm{Ci}$ & $\%$ & ${ }_{\mu} \mathrm{Ci}$ & $\%$ & $\mu \mathrm{Ci}$ & $\theta / 6$ & $\mu \mathrm{Ci}$ & $\%$ & $\mu \mathrm{Ci}$ & $\%$ \\
\hline $\begin{array}{l}\text { Negatively eharged } \\
\text { fraction } \\
\text { Amino acids + unknown }\end{array}$ & 0.006 & 0.3 & 0.008 & 2.2 & 0.013 & 3.4 & 0.028 & 2.6 & 0.008 & 6.5 & 0.009 & 1.2 \\
\hline compounds & 0.003 & 1.1 & 0.016 & 4.4 & 0.016 & 4.2 & 0.020 & 1.9 & 0.005 & 4.4 & 0.004 & \\
\hline Choline & 0.010 & 0.4 & 0.001 & 0.1 & 0.005 & 1.2 & 0.002 & 0.2 & 0.007 & 5.7 & 0.007 & 0.8 \\
\hline Betaine & 0.008 & 0.3 & 0.006 & 0.5 & 0.006 & 1.6 & 0.025 & $2 . \overline{3}$ & 0.002 & 1.9 & 0.004 & 0.5 \\
\hline Chlormequat Chloride & 2.313 & 97.9 & 0.330 & 91.8 & 0.347 & 90.0 & 0.989 & 93.0 & 0.099 & 81.5 & 0.750 & 97.0 \\
\hline Total & 2.342 & 100.0 & 0.361 & 100.0 & 0.387 & 100.0 & 1.064 & 100.0 & 0.121 & 100.0 & 0.774 & 100.0 \\
\hline
\end{tabular}

a For total activity of water soluble compounds compare Table 1.

Of these $10 \%$ one-third was in the most actively growing part of the plants. To study the possible occurrence of chlormequat or a breakdown product in nucleic acids of the actively growing part of the plants nucleic acids were extracted. Purity of the fraction was found to be high, since the ratio of extinction at the maximum and minimum was $\mathrm{E}_{\max } / \mathrm{E}_{\min }=2$ and that of the extinction at $260 \mathrm{~nm}$ and $280 \mathrm{~nm}$ was $\mathrm{E}_{260} / \mathrm{E}_{230}=1.8$. A total of $0.845 \mathrm{mg}$ RNA + DNA was extracted from $210 \mathrm{mg}$ fresh weight tissue. Specific activity was found to be $96 \mathrm{dpm} / \mathrm{mg}$ RNA + DNA indicating a negligible incorporation of chlormequat or a breakdown product into the total nucleic acid fraction.

\section{Protein and Water Soluble Fraction}

After the failure to detect distinct amounts of radioactivity in the nucleic acid fraction more attention was paid to the possible occurrence of radioactivity in the TCA-insoluble protein fraction of roots and above ground parts. Table 1 shows a balance sheet for chlormequat at different periods after the uptake periods. Directly after the uptake period most radioactivity is in the free water soluble fraction of the roots. Relatively small, but distinct amounts of radioactivity were present in the fraction containing plastids and mitochondria (Fig. 1, step 3B) and in the protein fraction of the roots (Fig. 1, step 5).

During the first week after the uptake period large amounts of radioactivity (water-soluble fraction) disappeared from the roots and entered the above-ground parts (Table 1) where it was present mainly as chlormequat (Table 2). At the same time the amount of radioactivity in the protein fraction, the cell wall residues

TABLE 3

Specific Activity of Protein Fraction from 20 Wheat Plants at Different Periods After the Uptake of $1,2{ }^{-14} \mathrm{C}$ Chlormequat

\begin{tabular}{|c|c|c|c|c|c|c|c|c|c|c|}
\hline \multirow[t]{2}{*}{$\begin{array}{l}\text { Days } \\
\text { after } \\
\text { uptake } \\
\text { period }\end{array}$} & \multicolumn{2}{|c|}{$\begin{array}{l}\text { Fresh weight } \\
\qquad(\mathrm{g})\end{array}$} & \multicolumn{2}{|c|}{ Protein (mg) } & \multicolumn{2}{|c|}{$\begin{array}{l}\text { Protein (mg) } \\
\text { resh weight }(\mathrm{g})\end{array}$} & \multicolumn{2}{|c|}{ Protein (dpm) } & \multicolumn{2}{|c|}{$\begin{array}{l}\text { Protein sp. } \\
\text { activity } \\
\text { dpm mg }\end{array}$} \\
\hline & Roots & Leaves & Roots & Leaves & Roots & Leaves & Roots & Leaves & Roots & Leaves \\
\hline 0 & 1.328 & 0.947 & 5.12 & 8.71 & 3.85 & 9.20 & 1.331 & 0 & 260 & 0 \\
\hline 7 & 3.227 & 4.794 & 3.93 & 51.38 & 1.22 & 10.72 & 50.740 & 21.312 & 12.911 & 413 \\
\hline 14 & 6.896 & 8.920 & 24.65 & 9.5 .88 & 3.58 & 8.91 & 93.054 & 11.544 & 3.775 & 120 \\
\hline
\end{tabular}


and plastid fraction of both roots and the above ground parts increased. Comparison between the period of 14 and 7 days after the uptake shows, with exception of the root protein fraction, a decline of radioactivity in all fractions (Table 1). Total radioactivity drops more rapidly in the second week than in the first week after the uptake of chlormequat.

\section{Analysis of the Protein H'raction}

The total protein content of the leaves increased steadily over a 2 wh period. The protein content of the roots, however, decreased first slightly and was followed by a rapid increase during the $7-14$ days period after the uptake of chlormequat (Table 3). With the exception of the leaves directly after the uptake period all protein fractions contained radioactivity, the highest specific activity was found after 7 days for both roots and leaves. Most important no distinct radioactivity could be detected in the low molecular fractions (Fig. 1, step 5, fraction 12 and 13), indicating no binding of chlormequat or breakdown products such as choline to the protein fraction.

Chlormequat is highly resistant to acid hydrolysis. However, upon hydrolysis of the protein fraction (Fig. 1, step 6) and subsequent chromatography of the hydrolysate in $n$-butanol-ethanol-acetic acid-water (8: 2:1:3) no radioactivity with an $R_{f}$ value equal to that of chlormequat or choline was detected, ruling out the possible occurrence of these compounds in the TCA insoluble protein fraction. The hydrolysate,
TABLE 4

Hydrolysis of the Protein Fraction of Rools $6 \mathrm{hr}$ After Uptake of 1,2-14 C Chlormequat

\begin{tabular}{lcc}
\hline & $\mathrm{dpm}$ & \%o of total \\
\hline Glycine & 568 & 46.8 \\
Serine & 288 & 23.7 \\
Unknown arnino acids & 357 & 29.4 \\
\multicolumn{1}{c}{ Total } & - & - \\
& 1213 & 99.9 \\
\hline
\end{tabular}

a A fraction containing $2.32 \mathrm{mg}$ protein and a total of $1633 \mathrm{dpm}$ was hydrolyzed to amino acids and run on an amino acid analyzer in citrate buffer.

contained amino acids and a number of unknown compounds since only $74 \%$ of the total radioactivity applied to the amino acid analyzer was recovered in the citrate buffer (Table 4). Two peaks of the eluate, containing together $80 \%$ of the radioactivity, coincided with non-radioactive labeled serine and glycine. The amount of glycine was twice as high as that of serine.

As mentioned already several reports claim the breakdown of chlormequat (6-12) into choline. Oxidation of choline to betaine probably occurs in green plants along the same pathways as in bacteria and in animal tissues (24). Choline is oxidized first to betaine. Betaine is initially demethylated to form dimethylglycine which is further oxidized to form sarcosine and formaldehyde. Sarcosine is finally converted into glycine and subsequently the carbon atoms of glycine are utilized for the synthesis of serine [Fig. 2 and $(24,25)]$. These data made it likely that radioactive

$$
\begin{aligned}
& \underset{\text { chlormequat }}{2\left(\mathrm{CH}_{3}\right)_{3} \mathrm{NCH}_{2} \mathrm{CH}_{2} \mathrm{Cl}} \rightarrow \underset{\text { choline }}{2\left(\mathrm{CH}_{3}\right)_{3} \mathrm{NCH}_{2}^{*} \mathrm{CH}_{2} \mathrm{OH}} \rightarrow \underset{\text { betaine }}{2\left(\mathrm{CH}_{3}\right)_{3} \mathrm{NCH}_{2} \stackrel{*}{\mathrm{COOH}}} \rightarrow \underset{\text { dimethylglycine }}{2\left(\mathrm{CH}_{3}\right)_{2} \mathrm{NCH}_{2}{ }^{*} \mathrm{COOH}} \rightarrow
\end{aligned}
$$

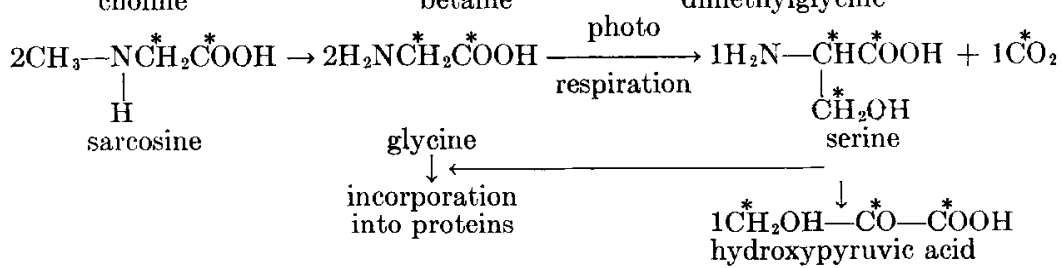

FIG. 2. Proposed pathway for the breakdown of $1,2-14 \mathrm{C}$ chlormeguat in wheat plants. * indicate positions of ruliventively labeled carbon atoms. 


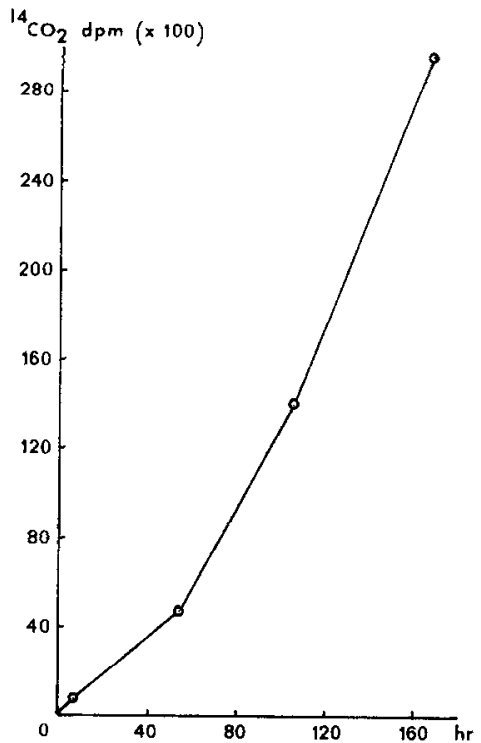

FrG. 3. ${ }^{14} \mathrm{CO}_{2}$ evolved by 20 wheat plants during 7 days after the uptake of $1,2^{14} \mathrm{C}$ chlormequat by the roots. The conditions and the total amount of ${ }^{14} \mathrm{CO}_{2}$ (in $\mu \mathrm{Ci}$ ) evolved are described in Table 5 .

choline derived from chlormequat formed the source for radioactive serine and glycine detected in the protein fraction.

\section{Analysis of the Water Soluble Fraction}

The above-mentioned pathway for the breakdown of chlormequat made it appropriate to investigate more in detail the free water soluble fraction (Fig. 1, step $3 \mathrm{~A}-7 \mathrm{~A})$. It will be clear that if chlormequat is finally broken down to amino acids the number of labeled compounds will increase rapidly in course of the growing period. Preliminary experiments showed that satisfactory separation of the many radioactive compounds in the water soluble fraction (Fig. 1, step 3A) could not be obtained, unless an initial separation of this fraction on cation exchange resin was carried out. Choline together with betaine were initially separated from chlormequat (Fig. 1, step $6 \mathrm{~A})$ and thereafter from each other using paper chromatography (Fig. 1, stcp 7B). In all cases the bulk of radioactivity consisted of chlormequat. The amount of choline plus that of betaine never exceeded that of $8 \%$ of the total radioactivity (Table 2). The ratio between choline and betaine in roots and leaves changed over the growing period, in most cases the amount of radioactivity of betaine was equal to or lower than that of choline.

To detect radioactive glycine and serine standards were added to the amino acid fraction of roots 7 days after the uptake period, and the fraction subjected to electrophoresis. Fourty two percent of the total radioactivity was recovered in one ninhydrin positive reacting color spot containing both glycine and serine. Another radioactive sample, when applied to the amino acid analyzer, yiclded two pcaks in a ratio 1:1 which coincided with glycine and serine.

No evidence for the occurrence of radioactively labeled dimethylglycine and sarcosine could be obtained.

\section{Evolution of ${ }^{14} \mathrm{CO}_{2}$ from Chlormequat-Treated Plants}

As has been shown in Table 1, 29\% of chlormequat taken up by wheat plants could not be recovered 7 days later. The

TABLE 5

Analysis of 20 Wheat Plants 7 Days After the Uptake of $1,2{ }^{14} \mathrm{C}$ Chlormequat Under Different Environmental Conditions ${ }^{a}$

\begin{tabular}{|c|c|c|c|c|c|c|c|c|c|c|c|}
\hline \multirow[t]{2}{*}{$\begin{array}{c}\text { Envirommental condi- } \\
\text { tions during } 7 \text { days } \\
\text { after uptake }\end{array}$} & \multirow{2}{*}{$\begin{array}{c}\text { Totul } \\
\text { amount } \\
\text { taken up } \\
(\mu \mathrm{Ci})\end{array}$} & \multirow{2}{*}{\multicolumn{2}{|c|}{$\begin{array}{c}\begin{array}{c}\text { Water-soluble } \\
\text { compounds } \\
(\mu \mathrm{Ci})\end{array} \\
\text { Roots Leaves }\end{array}$}} & \multicolumn{2}{|c|}{$\begin{array}{l}\text { Cell wall } \\
\text { residues } \\
(\mu \mathrm{Ci})\end{array}$} & \multicolumn{2}{|c|}{$\begin{array}{c}\text { Plastid } \\
\text { fraction } \\
(\mu \mathrm{Ci})\end{array}$} & \multicolumn{2}{|c|}{$\begin{array}{l}\text { Protein } \\
\text { fraction } \\
(\mu \mathrm{Ci})\end{array}$} & \multirow[t]{2}{*}{$\begin{array}{c}\mathrm{CO}_{2} \\
\text { evolved } \\
(\mu \mathrm{Ci})\end{array}$} & \multirow[t]{2}{*}{$\underset{(\mu \mathrm{Ci})}{\text { Recovery }}$} \\
\hline & & & & Roots & Leaves & Roots & Leaves & Roots & Leaves & & \\
\hline $\begin{array}{l}\text { Grow th chamber } \\
\text { Closed glass chamber (2) }\end{array}$ & $\begin{array}{l}2.907 \\
2.680\end{array}$ & $\begin{array}{l}0.571 \\
0.662\end{array}$ & $\begin{array}{l}1.425 \\
1.143\end{array}$ & $\begin{array}{l}0.017 \\
0.054\end{array}$ & $\begin{array}{l}0.000 \\
0.143\end{array}$ & $\begin{array}{l}0.048 \\
0.066\end{array}$ & $\begin{array}{l}0.001 \\
0.073\end{array}$ & $\begin{array}{l}0.013 \\
0.014\end{array}$ & $\begin{array}{l}0.003 \\
0.053\end{array}$ & $0 . \overline{133}$ & $\begin{array}{ll}2.087 & 71.8 \\
2.341 & 87.4\end{array}$ \\
\hline
\end{tabular}

- Under condition 1 the plants have been growing in an open grow th chamber, whereas under condition 2 the plants were grown in a closed glass chawter waking it possible to determine the auvuat of $\mathrm{CO}_{2}$ evulved. 
production of radioactively labeled scrine and glycine may be associated with the photorespiration activity of wheat plants (25). During photorespiration two molecules of glycine are utilized to produce one molecule serine and one molecule $\mathrm{CO}_{2}$. Moreover, serine may be transaminated to hydroxypyruvate in the glycolate pathway finally giving rise to the production of glucose (Fig. 2, 25 scheme 6-1). Therefore it could be expected that radioactively labeled carbon atoms of glycine would finally give rise to the evolution of ${ }^{14} \mathrm{CO}_{2}$ during photorespiration and respiration of wheat plants. To obtain a more complete balance sheet, plants fed with chlormequat for $6 \mathrm{hr}$ were transferred to a closed glass chamber and the evolution of ${ }^{14} \mathrm{CO}_{2}$ was measured during a $1 \mathrm{wk}$ period. As Fig. 3 indeed shows the evolution of radioactively labeled gas, presumably ${ }^{14} \mathrm{CO}_{2,}$, started soon after the transfer of plants to the glass chamber and increased with the time. Taking into account the amount of ${ }^{14} \mathrm{CO}$. released, $87.4 \%$ of chlormequat taken up by the roots could now be recovered (Table 5). Five per cent of the amount of chlormequat taken up was released as ${ }^{14} \mathrm{CO}_{2}$ within 7 days after the uptake period in the glass chamber which seems low as compared to the loss of $28.8 \%$ in the open growth chamber. However, it must be mentioned that growth of the plants was retarded as compared to normal growing plants outside the glass chamber. Whereas, inside the open growth chamber the fresh weight of the leaves increased by a factor of five (Table 3) that of the plants inside the closed glass chamber doubled only. As will be clear from Table 5 (water-soluble compounds) the relatively poor environmental conditions such as high humidity in the glass chamber retarded the translocation of chlormequat from the roots to the leaves. It may therefore be expected that under more natural conditions a higher percentage of the ${ }^{14} \mathrm{C}$ chlormequat taken up has been evolved as ${ }^{14} \mathrm{CO}_{2}$ in the open growth chamber.

\section{DISCUSSION}

In wheat plants radioactively labeled chlormequat was converted to radioactive choline, which was further metabolized to betaine. These results are consistent with those of Stephan and Schütte (12). Experiments described in this paper made it clear that betaine was demethylated and yiclded finally glycine and serine which were incorporated into the protein fraction according to the scheme as depicted in Fig. 2. The occurrence of radioactively labeled glycine and serine in the amino acid pool and the evolution of ${ }^{14} \mathrm{CO}_{2}$ from chlormequat treated plants indicated that serine was formed from glycine under the release of ${ }^{14} \mathrm{CO}_{2}$ during photorespiration. In addition it is conceivable that serine was further metabolized along the glycolate and glycolytic pathways yielding finally ${ }^{14} \mathrm{CO}_{2}$.

Choline undergoes also other reactions, the methyl groups are incorporated into alkaloids of barley and tobacco (12), whereas Belzile et al. (6) and Seibel et al. (26) showed that choline derived from chlormequat was converted into phosphatidyl choline and further incorporated in the phospholipid fraction. This result may explain the low radioactivity found in cell wall residues and the plastid fraction (Table 1).

In regard to the emphasis which is laid nowadays to decrease the hazards of unknown terminal residues it is of importance to note that careful examinations did not show the presence of chlormequat or unknown metabolites in the nucleic acid and TCA-insoluble protein fraction. In addition, no evidence for the presence of unknown metabolites could be obtained after analysing the water-soluble fraction. No radioactive peaks were found other than those already mentioned and therefore the unknown compounds listed in Table 2 must be regarded as a number of compounds which arose from choline. There seems to be only a small chance for the existence of unknown terminal residues since $87.4 \%$ of 
chlormequat could be recovered when taking into account the amount of ${ }^{14} \mathrm{CO}_{2}$ released (Table 5).

The published accounts of the rate of disappearance of chlormequat from wheat plants differ widely from each other. From Table 2 it appears that $50 \%$ of the unchanged chlormequat present in roots and leaves directly after the uptake period was already metabolized after 7.5 days. Fourteen days after the uptake period only $30 \%$ was left in the whole plants. Most probably the nonrecovered part has been evolved as ${ }^{14} \mathrm{CO}_{2}$. This result is most consistent with the results reported by Mooney and Pasarela. (13) and Jung and Fi-Fouly (10). The discrepancy with the results of Birecka (5) and Bohring (8) showing no decrease of chlormequat in wheat over a 4-wk period is difficult to explain. It is possible that the rate of disappearance strongly depends on the plant species and even on the variety used. This suggestion is in accordance with the different rates of disappearance of chlormequat in various plant species as found by Jung and El-Fouly (10) and by the strong persistence of chlormequat in potato plants (27). It can be inferred from Table 5 that different environmental conditions will also effect the rate of disappearance of chlormequat from plants. The rate of chlormequat breakdown may primarily be determined by the rate of formation of choline in various plant species. Wheat plant extracts contain an enzyme system which converts chlormequat into choline. This system is $\mathrm{pH}$-dependent and rather thermostable (9). The catalytic capacity of this system may differ considerably for the different plant species and varieties and offers so far the best explanation for the observed differences in rates of chlormequat breakdown.

\section{ACKNOWLEDGMENT}

The authors are indebted to Miss W. Meerdink for able technical assistance.

\section{REFERENCES}

1. H. M. Cathey, Physiology of growth-retarding chemicals, Annu. Rev. Plant Physiol. 15, 271 (1964).

2. N. M. de Vos, K. Dilı, and J. Bruinsma, Effects of 2-chloroethyltrimethylammonium chloride (CCC) on yield and lodging of wheat, Neth. J. Agr. Sci. 15, 50 (1967).

3. S. H. Wittwer, Growth regulants in agriculture, Outlook 6, 205 (1971).

4. R. C. Blinn, Plant growth regulant. Biochemical behavior of 2-chlorocthyl trimethylammonium chloride in wheat and in rats, J. Agr. Food Chem. 15, 984 (1967).

5. H. Birecka, Translocation and distribution of ${ }^{14}$ C-labelled (2-chloroethyl) trimethylammonium (CCC) in wheat, Bull. Acad. Pol. Sci. Cl. V. Ser. Sci. Biol. 15, 707 (1967).

6. L. Belzile, R. Paquin and C. Willemot, Absorption, translocation et métabolisme du chlorure de (2-chloroéthyl) triméthylammonium$1,2-{ }^{14} \mathrm{C}$ chez l'orge d'hiver (Hordeum vulgare), Can. J. Bot. 50, 2665 (1972).

7. H. Bier and W. Dedek, Zur Frage des Abbaues von ${ }^{15} \mathrm{~N}$ - und ${ }^{14} \mathrm{C}-\mathrm{Chlorcholinchlorid} \mathrm{(CCC)} \mathrm{in}$ höheren Pflanzen, Biochem. Physiol. Pflanzen (BBP) 161, 403 (1970).

8. J. Bohring, Abbau und Auswaschung von Chlorcholinchlorid bei Weizen, Z. Pflanzenernaehr. Dueng. Bodenk. 131, 179 (1972).

9. M. M. El-Fouly and J. Jung, Some factors affect the degradation of (2-chloroethyl) trimethylammonium chloride by wheat plant extracts, Experientia 25, 587 (1969).

10. J. Jung and M. M. El-Fouly, Uber den Abbau von Chlorcholinchlorid (CCC) in der Pflanzen, Z. Pfanzenernaehr. Dieng. Bodenk. 114, 128 (1966).

11. E. F. Schneider, Conversion of the plant growth retardant (2-chloroethyl) trimethylammonium chloride to choline in shoots of chrysanthemum and barley, Con. f. Biochem. 45, 395 (1967).

12. U. Stephan and H. R. Schiitte, Zum metabolismus von Chlorcholinchlorid in höheren Pflanzen, Biochem. Physiol. Pfanzen (BPP) 161, 499 (1970).

13. R. P. Mooney and N. R. Pasarela, Determination of chlorcholine chloride residues in wheat grain, straw, and green wheat foliage, J. Agr. Food Chem. 15, 989 (1967).

14. A. B. Morrison and I. C. Monro, Factors influencing the nutritional value of fish flour. IV. Reaction between 1,2-dichloroethane and protein, Can. J. Biochem. 43, 33 (1965).

15. J. Brook, S. H. West, and D. S. Anthony, Effects of Phosphon S on nucleic acid metab- 
olism in Pisum sativum Alaska, Plant Physiol. 42, 785 (1967).

16. A. A. Steiner, A universal method for preparing nutrient solutions of a certain desired composition, Plant and Soil 15, 134 (1961).

17. $H$. Veen, On the relation between auxin transport and auxin metabolism in explants of coleus, Planta 73, 281 (1967).

18. A. Fuchs and F. W. de Vries, A comparison of methodes for the preparation of ${ }^{14} \mathrm{C}$-labelled plant tissues for liquid scintillation counting, J. Appl. Rad. Isolop. 23, 361 (1972).

19. F. Solymosy, I. Fedorcsák, A. Gulyás, G. L. Farkas, and L. Ehrenberg, A new method based on the use of diethyl pyrocarbonate as nuclease inhibitor for the extraction of undegraded nucleic acid from plant tissues, Eur. J. Biochem. 5, 520 (1968).

20. O. H. Lowry, N. J. Rosebrough, A. L. Farr and R. J. Randall, Protein measurements with Folin phenol reagent, $J$. Biol. Chem. 193, 265 (1951).

21. H. Rosen, A modified ninhydrin colorimetric analysis for amino acids, Arch. Biochem. Biophys. 67, 10 (1957).

22. H. Bier and $H$. Faust, Zur quantitativen Bestimmung des Chlorcholinchlorids (CCC) im Pflanzenmaterial, Z. Chem. 5, 386 (1965).

23. J. Jung and G. Henjes, Bestimmung der Wachstumregulatoren CCC (Chlorcholinchlorid)und CMH ( $N$-Dimethyl- $N$ - $\beta$-chloräthyl-hydrazoniumchlorid) in biologischem Material, $Z$. Pflanzenernaehr. Dueng. Bodenk. 124, 97 (1969).

24. J. S. Fruton and S. Simmonds, Eds., "General Biochemistry," 3rd ed., p. 776, J. Wiley \& Sons, New York/London, 1960.

25. I. Zelitsch, in "Photosynthesis and Plant Productivity," p. 204, Academic Press, New York/London, 1971.

26. W. Seibel, W. Nurle, and A. W. El Baya, Einbau von Chlorcholinchlorid in die cholinhaltigen Lipide des Weizens. Z. Pflanzenphysiol. 69, 418 (1973).

27. H. M. Dekhuijzen and K. B. A. Bodlaender, Distribution and persistence of chlormequat in potato plants, Pestic. Sci. 4, 619 (1973). 